\title{
STRUCTURING OF STATUTORY VALUES OF POLISH TAX PROCEDURES
}

\author{
Andrzej Gorgol*
}

\begin{abstract}
This paper aims to provide a critical analysis of the regulation of statutory principles of tax proceedings under a preliminary assumption that the values of Polish tax procedures shall reflect the general determination of the legal system. An attempt was made to demonstrate that the structuring of axiology of these procedures does not fully account for this constitutional requirement.
\end{abstract}

Keywords: tax procedures, tax proceeding, values, principles, system, structuring

\section{INTRODUCTION}

In a democratic state of the law ${ }^{1}$, tax procedures shall be regulated by law, as they constitute proceedings conducted by public authority organs to which the constitutional obligation of these organs to operate on the basis and within the limits of law applies ${ }^{2}$. From this principle follow certain essential practical implications for the conduct of the tax procedure and the fulfilment of its aims. First, the tax organ shall determine whether

Dr. habil. Andrzej Gorgol, Associate Professor, Department of Administrative Law and Financial Law, Institute for Legal Sciences, University of Zielona Góra; correspondence address: ul. Bartnicza 15, 20-810 Lublin, Poland; e-mail: agorgol@gmail.com; https:// orcid.org/0000-0002-4313-4426.

1 See Article 2 of The Constitution of the Republic of Poland of 2d April, 1997 (Journal of Laws No. 78, item 483, as amended), hereinafter referred to as the Constitution.

2 See Article 7 of the Constitution. 
legal provisions grant it the competence to consider a certain matter. In case of a negative verification on the issue of competence is tantamount to the prohibition to initiate this procedure, let alone it conducts it. Any violation of the directive to refrain from taking any actions exceeding the scope tax organ competence constitutes a grave legal deficiency, which shall be eliminated even if the tax proceeding results in a final decision, and not only in cases where a non-final decision is appealed by parties during the proceeding. The gravity of the violation of law justifies a departure from the principle of stability of decisions which may not be challenged in the administrative course of the proceeding. A defective decision is declared invalid, which the tax organ merely determines ${ }^{3}$. Second, after the positive establishment of the legal basis for acting, the competent tax organ shall establish, in which legal form regulated by law, it will perform its public task. In such a case, the organ also does not have the freedom to act, as according to the rule of law it is obliged to operate on the basis and within the limits of the law. Administrative discretion does not infringe upon this systemic standard, and its application may be necessary due to the existence of open-ended terms in the legal provision and judicial discretion in the process of application of the law. A full binding of the organ with legal provisions during a tax procedure may cause that the outcome of this procedure will not consider all values of the system of law and its legal stipulations.

It is worth noting that the constitutional standard of legality positions the structure of tax administration within the legal system, but falls short in differentiating the legal form of acts and determining systemic solutions. In a democratic state of the law, all sources of binding law shall be observed. The multitude and variety of their legal forces pose challenges not only when constructing systemic contents, but also upon the application of the law. Undoubtedly, each system shall be internally coherent, i.e., free from contradictory or conflicting norms ${ }^{4}$. Moreover, no loopholes shall be

3 According to Article $247 \$ 1$ point 1 of the Act of 29 August 1997 - Tax Ordinance Act, (consolidated text, Journal of Laws of 2020 item 1325, amended), hereinafter referred to as the T.O.A.

4 Andrzej Gorgol, "Aksjologiczne uwarunkowania zmian w Ordynacji podatkowej. Wybrane problemy. Kierunki zmian," in Ordynacja podatkowa: stan obecny i kierunki zmian, ed. Rafał Dowgier (Białystok: Temida 2, 2015), 47-51. 
present in it. Specific elements of the legal system do not operate in separation, but they are rather interoperable. In addition, many complex and versatile normative, axiological, and praxeological links exist between them.

\section{STRUCTURING OF VALUES OF TAX PROCEDURES AS A LEGISLATIVE PROCESS}

Tax procedures are institutions located within the legal system. From this follows the next conclusion that their axiology should form a reflection of this system. Formulating procedural principles in the legislative process requires consideration of both systemic determinations and specific features of these procedures. Structuring of the values of Polish legal procedures is a law-making process which leads to the creation of a sui generis subsystem within the larger legal system. The essence of this process can be perceived as the adaptation of normative, axiological and praxeological systemic assumptions to the conditions in which the tax administration performs its public tasks. It is also manifested in the differentiation of the solutions of the legal system, thus increasing the level of its internal diversity. In this case, the legislative process ends up with the creation of a new structure which can be described by a sui generis paradox of multitude in unity and unity in multitude.

As has been noted, the axiology of the legal system has a constitutional grounding. Systemic values are differentiated from the legal perspective. Some of them have the form of legal provisions while others lack such form. It shall be stressed, however, that irrespective of such differentiation, all constitutional values should be reflected in the content of procedural provisions. Otherwise, a systemic inconsistency would occur and the principle of direct application of the constitution would be violated. Constitutional values stemming from legal provisions can be general or specific. Decoding their meaning requires the application of systemic interpretation, including argumentum a rubrica ${ }^{5}$ reasoning. The positioning of a given legal provision within the formal layout of the legal act is not

5 Jerzy Wróblewski, Rozumienie prawa i jego wyktadnia (Wrocław, Łódź, etc.: Zakład Narodowy im. Ossolińskich, 1990), 74; Lech Morawski, Wyktadnia w orzecznictwie 
accidental and is an indication of law-making reasonability. General provisions which have basic meaning for the application of the whole legal act are located before specific provisions having a more specialized character and a narrower scope of application. Undoubtedly, the already mentioned constitutional rule of lawfulness, which is located in Chapter I of the Constitution of the Republic of Poland titled "the Republic of Poland" belongs to them. The principle of two instance proceedings has a more specific character ${ }^{6}$, as in the Constitution, it is considered in the context of measures for the protection of rights and freedoms of the citizen and the individual. It fulfils with additional meaning the systemic standard of legality, albeit in scope limited to the challenging of decisions and rulings issued in the first instance. Constitutional values which do not have the form of a legal provision are included in turn in the Preamble which forms an integral part of the Constitution ${ }^{7}$. This introduction underlines the solemn significance of the legal act, describes the circumstances of its adoption, and indicates the aims whose realization it is to serve. The preamble to the Constitution plays an important role both in the systemic and functional interpretation of the binding law $^{8}$. The axiology of this part of the Constitution serves also as a legislative directive for formulating of the values of tax procedures ${ }^{9}$.

The axiology of tax procedures is regulated in the Tax Ordinance which does not include a preamble. A preamble was neither provided for in the draft new codification of the general tax law ${ }^{10}$. This omission may cause doubt since the Tax Ordinance constitutes a significant legal

sądów. Komentarz (Toruń: Towarzystwo Naukowe Organizacji i Kierownictwa „Dom Organizatora”, 2002), 198-199.

6 See Article 78 of the Constitution.

7 Sławomir Lewandowski, "Charakter normatywny preambuły," Studia Iuridica 36 (1998): 114-136.

8 Małgorzata E. Stefaniuk, Preambuta aktu normatywnego $w$ doktrynie oraz procesie stanowienia i stosowania polskiego prawa w latach 1989 - 2007 (Lublin: Wydawnictwo UMCS, 2009), 62, 96, 115.

9 Gorgol, "Aksjologiczne," 50.

10 Rządowy projekt ustawy - Ordynacja podatkowa., Druk Sejmowy nr 3517 z dnia 4 czerwca 2019 r. (The Bill - Tax Ordinance Act, introduced by the Council of Ministers to the Sejm, The Printing of The Sejm of 4 June 2019). 
act rightly dubbed as the code of the taxpayer ${ }^{11}$. From the viewpoint of regulating tax procedures, the meaning of the Tax Ordinance is more pronounced than the one of the Act on the National Tax Administration ${ }^{12}$, which is an incomplete and specific way regulating tax procedures. In the case of customs and tax inspection, the Tax Ordinance has a mutatis mutandis application that is in consideration of the distinction of this procedure $^{13}$. The Act on the National Tax Administration begins with a preamble which underlines the meaning of the constitutional obligation to pay public levies ${ }^{14}$, fiscal security and its protection, the modern and favorable performance of public obligations and effective collection of public levies ${ }^{15}$. This legal act regulates above all issues connected with the structure and forms of operation of tax administration and serves as a professional circular. The normative matter of its content justifies thus its qualification as a systemic law. The preamble points to the axiology of the National Tax Administration, which has significance only in the realization of tax procedures by governmental tax organs. The values enumerated at the beginning of this act do not substitute the values of the tax proceedings set out in the Tax Ordinance, but specify them in a limited scope. For this reason, one may conclude that the model statutory values of tax procedures are included only in the Tax Ordinance and have only a normative character.

The legislative process leading to the structuring of the values of tax procedures requires conferring the proper legal form to normative solutions. Axiology should not be regulated by acts of internal management ${ }^{16}$, which are bounded only within the framework of hierarchical subordina-

11 Andrzej Gorgol, "Zagadnienia ogólne," in Prawo podatkowe, eds. Paweł Smoleń, and Wanda Wójtowicz (Warsaw: Wydawnictwo C.H. Beck, 2015), 77; Andrzej Gorgol, “Ordynacja podatkowa, czy daninowa?," Państwo i Prawo 4 (2013): 3-14.

12 The Act of 16 November 2016 of The National Revenue Administration, (consolidated text, Journal of Laws of 2019 item 768, amended), hereinafter referred to as the N.R.A.

13 See Article 94 of the NRA.

14 See Article 84 of the Constitution.

15 Andrzej Gorgol, "Uwagi wstępne," in Ustawa o Krajowej Administracji Skarbowej. Komentarz, eds. Leszek Bielecki, and Andrzej Gorgol (Warsaw: Wydawnictwo C.H. Beck, 2018), 2-3.

16 See Article 93 of the Constitution. 
tion of lower organs, offices, and organizational units to the administrative organ of a higher rank. The influence of the values of tax procedures extends also to entities outside the administrative structure. The acts of internal management may not form sources of rights and obligations to the participants of tax procedures. As has been mentioned, the axiology of the legal system shall be coherent, as it plays an important role in the application of the law on the whole territory of the country. It is for this reason that the values of tax procedures shall not be stipulated in the content of the statutory authorizations conferring legislative competence to pass local legal acts with a scope of application limited to the territory of a given territorial unit of the country ${ }^{17}$. It is also improper to regulate values in the form of executive regulations which are applied on the territory of the whole country, but their normative matter is limited to casuistic issues, technical from the viewpoint of creating necessary conditions for the realization of the statute ${ }^{18}$. The axiology of tax procedures shall have at minimum a statutory form. From it follows directives binding on the administrative organs and shaping the legal standing of the participants of the proceeding. Tax procedures interfere with constitutionally protected rights and freedoms. ${ }^{19}$. In a democratic state of the law, the basis of such interference may only be a statute. The axiology of tax procedures can be shaped not only by Poland but also by organs functioning on a supranational level. Legal acts issued at this level have a dual legal effect. On the one hand, they become an element of the domestic legal system, on the other they apply in relations between different public and international law entities. Both prerequisites are met in the case of the provisions of the EU law which are directly applicable in Poland and in the case of bilateral and multilateral international agreements, ratified by Poland and published in the Official Journal of Laws ${ }^{20}$.

17 See Article 94 of the Constitution.

18 See Article 92 of the Constitution.

19 Means for the defence of freedoms and rights are especially regulated by Articles 77-81 of the Constitution.

20 Compare Article art. 97 section 1, Article 89, Article 90, Article 91 of the Constitution. 


\section{THE ESSENCE OF STATUTORY VALUES OF TAX PROCEDURES}

The Tax Ordinance regulates three main tax procedures, i.e. tax proceeding $^{21}$, verification activities ${ }^{22}$, and tax inspection ${ }^{23}$. In the first place, one needs to establish whether they have a common axiology and if they are characterized by distinct values. From the substantive and formal point of view, these three procedures constitute separate proceedings ${ }^{24}$. Tax proceeding is a jurisdictional proceeding meaning it is directed at issuing a binding resolution of a tax matter. As a specific form of the administrative proceeding, it furnishes in principle with an administrative decision ${ }^{25}$. Tax inspection is a procedure whose aim is to verify the conformity with the tax law provisions of entities bound by them ${ }^{26}$. A tax organ reaches factual determinations which it compares with specific law provisions and documents its activities in an inspection protocol ${ }^{27}$. Verification activities are a procedure with a less formalized level and different scope of application. They aim to verify the timeliness and correctness of the performance of the taxpayer's payment obligation, filing of tax declarations, calculation of tax deductions, and applications for tax returns, as well as other obligations ${ }^{28}$. The legal position of entities subject to verification procedures tends to be weakened to concerning the entities subject to tax inspection. Less formalization of these activities and the fact that they are not deemed a control procedure causes that certain essential limitations protecting en-

21 See Division IV of the T.O.A.

22 See Division $\mathrm{V}$ of the T.O.A.

23 See Division VI of the T.O.A.

24 Gorgol, "Prawne," 140-145; Andrzej Gorgol, "Dekodyfikacja postępowań administracyjnych w sprawach finansowych," in Kodyfikacja postępowania administracyjnego. Na 50-lecie k.p.a., ed. Janusz Niczyporuk (Lublin: Wydawnictwo WSPA, 2010), 189-198; Andrzej Gorgol, "Postępowanie podatkowe jako szczególny rodzaj postępowania, administracyjnego," in Zarys finansów publicznych i prawa finansowego, ed. Wanda Wójtowicz (Warsaw: Wolters Kluwer Polska, 2014), 200-201; Andrzej Gorgol, "Odrębności aksjologii postępowania podatkowego," in Aksjologia prawa administracyjnego, Vol. 1, ed. Jan Zimmermann (Warsaw: Wolters Kluwer Polska, 2017), 1137-1148.

25 See Article $207 \$ 1$ of the T.O.A.

26 See Article $281 \$ 2$ of the T.O.A.

27 See Article $291 \$ 2$ and $\$ 2$ of the T.O.A.

28 See Article 272 of the T.O.A. 
trepreneurs subject to inspection are not applied ${ }^{29}$. Formal distinction of these three procedures is further confirmed by the fact that they are regulated in separate, general redaction units of the statue, i.e., sections. It is also worth to note the sequence of their appearance. In the first place, the tax proceeding is regulated, followed by verification activities and tax inspection. The most extensive is the normative subject matter of the section called "tax proceedings" and the two following sections contain fewer provisions. Such an approach shall be viewed as proper, ${ }^{30}$ as it is unnecessary to repeat the same regulations in different redaction units of the statute. In such cases, an instrument of the law-making technique called a reference is applicable. In the sections regulating verification activities and tax inspections included are provisions referring to the respective application of enumerative listed provisions on tax proceedings ${ }^{31}$. This leads to the conclusion that the tax proceeding is a model tax procedure. From the legislative point of view, it is almost self-contained. Verification activities in turn and tax inspection are specific procedures characterized by solutions departing from the model of tax proceedings. Provisions located in the following two sections after the part regulating tax proceedings govern only the distinctive features of these proceedings. These regulations need to be supplemented by tax proceedings provisions for the verification activities and tax inspection to be realized. In this legislative sense, they are incomplete and not self-contained.

There are two arguments in favour of acknowledging that there is a common axiology of tax procedures. First, sections called 'verification procedures' and 'tax inspection' do not include provisions directed at regulating the catalogue of values of these two proceedings. Second, provisions referring to the respective application to regulations of tax proceedings include also those which are called 'general principles' 32 . It follows that the values of tax procedures constitute the principles of procedural tax

29 According to Article 291c of the T.O.A. control of economic activity of a taxpayer that is an entrepreneur shall be governed by the provisions of Chapter 5 of the Act of 6 March 2018 - Entrepreneurs' Law (consolidated text Journal of Laws of 2019 item 1292, amended).

30 Gorgol, "Aksjologiczne," 56-57.

31 Compare Article 280 and Article 292 of the T.O.A.

32 Chapter 1 Division IV of the T.O.A. 
law. The normative character translates into their binding force. As has been mentioned before, they form directives for the tax organ. For the taxpayer, in turn, they operate as guarantees of its rights rather than sources of its obligations.

A normative description of the general principles includes the adjective 'general' which causes an internal differentiation of statutory values of tax procedures. General principles can be contrasted in terms of a dichotomy with specific principles ${ }^{33}$. The feature of being general shall not be understood as encompassing the totality of principles, a common set of all principles of the generality of operational directives. General principles are rather characterized by the fact that they apply to the whole tax procedure. Legal provisions may, of course, introduce exceptions to these principles. In practice, not every procedural activity may be shaped according to the requirements of the given principles. A synonym of generality is the universality of the said principle. Specific principles in turn have a more narrow scope of application limited to specific stages of the proceedings. In practice, they play an important role in the evidentiary proceeding, which is manifested by the principle of free evaluation of evidence ${ }^{34}$. The term 'general principles' is not a legal notion in which legal provisions are worded. For these reasons, one may classify them as unnamed principles. As all principles of tax procedures, they have a normative character and their application, apart from tax proceeding, to verification activities and tax inspections is grounded in the respective referencing provisions.

The in dubio pro tributario principle may find application in all tax procedures and is stipulated in the Tax Ordinance ${ }^{35}$. For this reason, it may not be viewed as a specific principle. A question arises, however, whether it is one of the general tax principles? An answer to this question must be negative. The in dubio pro trubutario principle has application to all provisions of tax law, both substantive and procedural. It contains an interpretational directive applicable to dubious provision in favour of a taxpayer. This principle finds application to all, both general and specific principles of tax procedures. In practice, the in dubio pro tributario principle is

33 Gorgol, "Aksjologiczne," 57-58.

34 See Article 191 of the T.O.A.

35 See Article $2 \mathrm{a}$ of the T.O.A. 
a 'met principle,' i.e. the principle of principles for tax proceedings. It plays an important role in the application of this law, and not in the lawmaking phase in which the structuring of values of tax procedures occurs.

\section{THE INTERNAL STRUCTURE OF STATUTORY VALUES OF TAX PROCEDURES}

One should underline in the first place that there exists a multitude of statutory values of tax procedures. The set of general principles has the form of a closed catalogue ${ }^{36}$ and specific principles are not listed in such a catalogue, which does not mean that their number is not limited by legal provisions. As has been noted, there exists a hierarchy between constitutional and statutory values in that general and specific statutory values are subordinate to constitutional standards. This hierarchy reflects the distinctive legal force of legal acts and their situation within the Polish legal system. General principles in turn are superior towards specific principles.

The issue of the structuring of statutory values of tax procedures necessitates also the assessment of their internal relations, i.e. the links existing within each group of such principles. This issue is important to determine whether in Polish law there exists a subsystem or subsystems of values of tax procedures. A multitude of values is necessary for the existence of one common system for all statutory values of a subsystem, as well as for the existence of separate systems grouping general and specific values. Similar to the legal system, the constituent elements of a subsystem may not be a chaotic, but rather an ordered set. Their order stems from their functional influence, and not from the differentiation of their legal force. From the formal point of view, all general and specific principles have the same statutory rank. Distinct scope of application of both groups of values, however, speaks to the discernment of the two subsystems.

From the legislative point of view, no subsystem of statutory principles has a hierarchically constructed internal structure. This means that each element is equivalent to other elements of the set. Grammatical and linguistic interpretation of legal provisions regulating the statutory axiology

${ }^{36}$ Chapter 1 Division IV of the T.O.A. 
of tax procedures supports the notion that there is no place for hierarchy in their content. Depending on the approach adopted, they can be distinguished as to their substance. The first approach accounts for the situation of a given principle among statutory provisions, which allows for argumentum a rubrica reasoning. In this approach, the order of regulating tax procedure values in a given legal act is of significance. The research is subject to horizontal analysis. The second approach accounts for the situation of principles and their regulating legal acts within the whole legal system. What is analyzed are the internal relations between statutory tax procedure values. The research is subject to vertical analysis. This leads to a hierarchy of values under consideration of the indirect influence of provisions of a higher legal force on the content of statutory regulations. This means that the higher rank in the subsystem of statutory values of tax procedures is occupied by those principles which to a higher degree are aligned with constitutional standards.

The catalogue of general principles of tax procedures is set out in 10 statutory articles ${ }^{37}$. This does not mean that their number is equivalent to the number of these articles. In reality, there are more principles than the redaction units as one of the articles sets forth two principles, i.e. the conduct of the proceeding in a manner, increasing trust in tax organs $s^{38}$ and informing the participant of tax proceeding about the tax law provisions which are in connection with the pending proceeding ${ }^{39}$. The statutory catalogue is opened by the principle of legality ${ }^{40}$ and closed with the principle of restriction of proceedings' transparency only to its parties ${ }^{41}$. The remaining principles are enumerated as follows: the principle of conducting proceedings in a manner increasing trust in tax organs, the principle of informing the participant to the proceedings about tax legal provisions in connection with the pending proceedings, the reliability principle ${ }^{42}$, the principle of active participation at its stage of proceedings ${ }^{43}$, the princi-

\footnotetext{
37 From Article 120 of the T.O.A. to Article 130 of the T.O.A.

38 See Article $121 \$ 1$ of the T.O.A.

39 See Article $121 \$ 2$ of the T.O.A.

40 See Article 120 of the T.O.A.

41 See Article 129 of the T.O.A.

42 See Article 122 of the T.O.A.

43 See Article 123 of the T.O.A.
} 
ple of persuasion ${ }^{44}$, the principle of promptness and efficiency ${ }^{45}$, the principle of written nature of proceedings ${ }^{46}$, the principle of two instance proceedings ${ }^{47}$, the principle of the relative stability of a final decision ${ }^{48}$.

Application of the second criterion of the hierarchy of values of tax procedures causes changes in their sequence motivated by the order of their appearance in the statutory catalogue. Prima facie, the legality principle was mentioned in the first place among the values of tax proceedings. As has been noted, this principle forms the fundamental standard of the functioning of the democratic state of law. When comparing its meaning in the statutory and constitutional approach, one may conclude that its inclusion in the statutory catalogue not only does not bring anything new concerning the constitutional formulation but also limits its conten ${ }^{49}$. In the statutory sense, the legality principle contains only one operational directive based on legal provisions. What has been wrongly omitted is the constitutional requirement to operate within the limits of the law. This legislative error renders the statutory principle of legality redundant as the constitutional standard has a direct application. When applying this conclusion to all values, one can generalize that the inclusion in the statutory catalogue of a value is only then reasonable when it adds a new meaning to the meaning stipulated in the constitutional standard. It is not proper to repeat the same meaning in different legal provisions, let alone its limitation to the solution adopted in a legal act of a higher legal force. It shall be then concluded that the legality principle in its current statutory wording is inappropriately included in the statutory catalogue, let alone it beginning the sequence of the general principles.

It is to be stressed that all statutory values of tax procedures are linked to the constitutional principle of the democratic state of the law if they are formulated appropriately from the legislative perspective. Some of them account for other constitutional standards. They shall be thus located higher within the structure of general principles; this applies to, for example.

44 See Article 124 of the T.O.A.

45 See Article 125 of the T.O.A.

46 See Article 126 of the T.O.A.

47 See Article 127 of the T.O.A.

48 See Article 128 of the T.O.A.

49 Compare Article 7 of the Constitution and Article 120 of the T.O.A. 
the principle of two-instance proceedings which is currently mentioned in the last but one place of the catalogue. Moreover, the principle of limited transparency is unnecessarily located as one of the last general principles, as it should not be linked to the transparency of public finances, but rather to the protection of privacy and personal data ${ }^{50}$.

The functional interrelations between the general principles influence the structuring of values of tax procedures. As has been mentioned above, the principles shall be applied in the narrowest possible scope. Sometimes collisions may appear between directives stemming from these principles. For example, the necessity to establish all relevant circumstances for the resolution of a given case, as necessitated by the reliability principle ${ }^{51}$, may cause complexity and prolongation of proceeding. In such a case, these implications are not in line with the principle of swiftness and simplicity of the proceeding ${ }^{52}$. When considering the issue of praxeological links between the general principles, it shall be stressed that the legality principle, when construed properly, shall be located at the peak of the structure of the statutory axiology of tax procedures. It forms the principle of general principles as the violation of any other principles is tantamount to the breach of the legality principle. In the structure of the values of tax procedures, the principle of active participation at all stages of the procedure ${ }^{53}$ has in praxeological terms a higher rank than the reliability principle. This is connected with the conditioning of the establishment of all material facts to the resolution of the tax case upon the opportunity of the party to the tax proceedings to take a position on the conducted evidence ${ }^{54}$.

The subsystem of specific principles is to a large extent dispersed and the lack of their pronunciation and the statutory catalogue may cause controversies connected with the number and naming of these principles. As has been noted, specific principles play a significant role in regulating the evidentiary proceeding. In jurisprudence, three examples of principles of this stage of tax procedure are named, i.e. the principle of objective

\footnotetext{
50 Compare Articles 47 and 51 of the Constitution.

51 See Article 122 of the T.O.A.

52 See Article $125 \$ 2$ of the T.O.A.

53 See Article 123 of the T.O.A.

54 See Article 192 of the T.O.A.
} 
truth, the principle of free evaluation of evidence and the principle of active participation of a party in the evidentiary proceeding 55 . It is noteworthy that among this enumeration two general principles linked to the conduct and assessment of evidence appear. Only the principle of free evaluation of evidence is a typical specific principle. In one article it has been pointed at the appearance of the principle of the equal evidentiary weight of evidentiary means, where it has been stressed that the application of a formal theory of evidence by assuming that a given circumstance can only be proved by specific evidentiary means ${ }^{56}$. In contrast to the discernment of a subsystem of general principles, the standardization degree of specific principles is less advanced. It shall be concluded that there is no formal hierarchy, neither vertical nor horizontal. Provisions regulating these principles are mentioned in the statute in given order. This is, however, caused by the peculiarities of the procedure and not by the rational approach aimed at conferring a special meaning to these principles. The criterion of the relation of these principles to the constitutional standards and general principles of tax procedures also appears baseless in creating a hierarchy of values applicable to specific stages of the procedure. It is to be stressed that any comparison of the meaning of values has only the sense, when they have common scopes of application. Specific principles are, however, stipulated in different phases of tax proceedings.

\section{CONCLUSIONS}

Structuring statutory values of tax procedures may be analyzed as an effect of an already concluded legislative procedure or a task which requires an amendment of already binding provisions of the law to optimize their application. Undoubtedly, these principles have a normative character and their structuring shall consider the determinations of the Polish

55 Bogumił Brzeziński, Marek Kalinowski and Marian Masternak, Ordynacja podatkowa - postępowanie - komentarz praktyczny (Gdańsk: Ośrodek Doradztwa i Doskonalenia Kadr, 1999), 118-123.

56 Piotr Pietrasz, "Komentarz do art. 180," in Ordynacja Podatkowa, eds. Cezary Kosikowski, Leonard Etel, Rafał Dowgier, Piotr Pietrasz, and Sławomir Presnarowicz (Warsaw: Wolters Kluwer Polska, 2007), 669-670. 
legal system. It is undesirable if collisions or contradictions occur between the axiology of tax procedures and constitutional standards. Internal axiological contradiction in the system of law is presented when the values enumerated in the provisions of the basic statute (the Constitution) and its preamble are violated. This drawback can have undesired legislative, functional or praxeological consequences contrary to the principle of the democratic state of law and which impede the process of correct interpretation of procedural provisions of the tax law, and their application in specific cases. In this context, one may conclude that the existence of the defect of the statutory principle of legality, which content is determined too narrow to in regard to its constitutional model. The omission of the obligation of the tax organ within the confines of the law, and not only based on law, can be eliminated only after the application of the constitution-friendly interpretation of the statutory provision. The general principle of legality is redundant since the provisions of the Constitution are directly applicable and have a superior legal force. From the viewpoint of correct legislation, it is also improper to repeat the content of a legal provision of the act with higher rank without any modification thereof, as well as to omit essential provisions.

Structuring statutory values of tax procedures in the Tax Ordinance required consideration of the division of such procedures in tax proceedings, verification activities and tax inspection. Undoubtedly, despite the existence of differences in their nature, functions and legal regulation, it can be underlined that the axiology forms an element linking all these procedures. Structuring the statutory values of tax procedures was based on the supposition that principles of tax proceedings serve as a model for their application and also in other proceedings. Four determinants of the legislative process follow. First, there arises a necessity to fully regulate all principles of tax proceedings with statutory provisions. Second, the analogical regulation of values of verification activities and tax inspection in provisions referring to these procedures has been discarded. Third, a reference to the regulations of the tax proceeding has been applied in these provisions. Fourth, because of distinctions in verification activities and tax inspection, the provisions on the values of tax proceedings may find mutatis mutandis application to them and may not be applicable directly. The above- mentioned legislative steps should be deemed appropriate. 
Structuring the statutory values of tax procedures, as well as of the axiology of the remaining tax procedures, has both a horizontal and vertical dimension. It also caused a differentiation of these principles, which may have a general or specific character. The level of structuring of general principles is more advanced than the specific principles. From the normative perspective, it manifests itself in equipping the term "general principles" with characteristics of the legal language and employing it as the statutory nomenclature for describing the redaction units of the Tax Ordinance referring to the axiology of tax proceedings. They include a closed catalogue of such principles. Specific principles in turn are regulated to an insufficient degree, which causes doubts connected with their number, names, content and even their existence.

Multitude and heterogeneity of principles of tax proceedings are the basic tenets determining the hierarchy of values which occurs in the form of the structuring of statutory values in tax procedures. In a vertical perspective, it considers the structure of the Polish legal system. Statutory values are subject to the axiology of legal acts of a higher rank, i.e. not only constitutional standards but also the provisions of EU law applied directly in Poland and ratified international agreements published in the Official Journal of Laws of the Republic of Poland. The division into general and specific principles influences their vertical hierarchy. Despite the same legal force, the general principles of tax proceedings override its specific principles. It seems not only from the higher level of their legal regulation but above all from the subject matter scope of their application during the tax procedure. Structuring of general and specific principles of tax proceedings leads to the situation in which they co-exist as two subsystems of tax procedure values.

In a horizontal view, the hierarchy of specific values is unwarranted. It is supported by not only insufficient level of their structuring, divergent scopes of application, but also the lack of functional interrelationships. Characteristics of the subsystem of general principles allow for a hierarchy of these values within their internal structure. The highest rank shall be ascribed to values whose content has a direct reference to the constitutional standards. Axiological links between general principles of tax procedures and constitutional standards may not account for these overarching principles which are common to the whole statutory structure. Application 
of the systemic rule of the democratic state of the law does not allow for the differentiation of general principles and discernment of their position within the axiological hierarchy, as all statutory principles shall account for this rule. Apart from the constitutional criterion, in the horizontal structuring of the general values of the tax procedures, arguments referring to argumentum a rubrica employed in the systemic interpretation of the law may be considered. It shall be postulated that the order of situation of the general principle in the statutory catalogue reflects its axiological meaning. More important values should be regulated before the remaining values. The Tax Ordinance falls short of this requirement. This is evidenced, for example by situating in the statutory catalogue of a less important value of written proceedings before the principle of two instance proceedings, which directly refers to the axiological constitutional standard. The functional and praxeological links between the values shall be included subsequently after the constitutional criterion. This is why the principle of active participation of the parties at all stages of the proceedings occupies a higher rank in the hierarchy of general principles than the principle of reliability of the proceedings.

The legislative criterion has no less important meaning in the structuring and hierarchy of tax procedure values, which accounts for the current order of regulating general principles. It stems from the assumption of the reasonableness of the lawmaker which is not fully confirmed in this paper. The necessity to adapt the content of the statutory catalogue of general principles to their axiological meaning is not only motivated by doctrinal considerations. Ordering of the sequence of the occurrence of these principles may facilitate the interpretation of procedural provisions of tax law and their application in the practice of tax organs.

\section{REFERENCES}

Brzeziński, Bogumił, Marek Kalinowski, and Marian Masternak. Ordynacja podatkowa - postępowanie - komentarz praktyczny. Gdańsk: Ośrodek Doradztwa i Doskonalenia Kadr, 1999.

Gorgol, Andrzej. "Aksjologiczne uwarunkowania zmian w Ordynacji podatkowej. Wybrane problemy. Kierunki zmian." In Ordynacja podatkowa: stan obecny 
i kierunki zmian, edited by Rafał Dowgier, 47-51, 50, 56-57, 57-58. Białystok: Temida 2, 2015.

Gorgol, Andrzej. "Dekodyfikacja postępowań administracyjnych w sprawach finansowych.” In Kodyfikacja postepowania administracyjnego. Na 50-lecie k.p.a., edited by Janusz Niczyporuk, 189-198. Lublin: Wydawnictwo WSPA, 2010. Gorgol, Andrzej. "Odrębności aksjologii postępowania podatkowego." In Aksjologia prawa administracyjnego, Vol. 1, edited by Jan Zimmermann, 1137-1148, Warsaw: Wolters Kluwer Polska, 2017.

Gorgol, Andrzej. “Ordynacja podatkowa, czy daninowa?.” Państwo i Prawo 4 (2013): 3-14.

Gorgol, Andrzej. "Postępowanie podatkowe jako szczególny rodzaj postępowania administracyjnego." In Zarys finansów publicznych i prawa finansowego, edited by Wanda Wójtowicz, 200-201. Warsaw: Wolters Kluwer Polska, 2014.

Gorgol, Andrzej. "Prawne aspekty kodyfikacji procedur podatkowych." In Prawo podatkowe, edited by Paweł Smoleń, and Wanda Wójtowicz, 140-145. Warsaw: Wydawnictwo C.H. Beck, 2015.

Gorgol, Andrzej. "Uwagi wstępne.” In Ustawa o Krajowej Administracji Skarbowej. Komantarz, edited by Leszek Bielecki, and Andrzej Gorgol, 2-3. Warsaw: Wydawnictwo C.H. Beck, 2018.

Gorgol, Andrzej. “Zagadnienia ogólne.” In Prawo podatkowe, edited by Paweł Smoleń, and Wanda Wójtowicz, 77. Warsaw: Wydawnictwo C.H. Beck, 2015.

Lewandowski, Sławomir. "Charakter normatywny preambuły." Studia Iuridica 36 (1998): 114-136.

Pietrasz, Piotr. "Komentarz do art. 180." In Ordynacja Podatkowa, edited by Cezary Kosikowski, Leonard Etel, Rafał Dowgier, Piotr Pietrasz, and Sławomir Presnarowicz, 669-670. Warsaw: Wolters Kluwer Polska, 2007.

Stefaniuk, Małgorzata E. Preambuta aktu normatywnego $w$ doktrynie oraz procesie stanowienia i stosowania polskiego prawa w latach 1989 - 2007. Lublin: Wydawnictwo UMCS, 2009.

Wróblewski, Jerzy. Rozumienie prawa i jego wyktadnia. Wrocław, Łódź, etc.: Zakład Narodowy im. Ossolińskich, 1990.

Morawski, Lech. Wyktadnia w orzecznictwie sądów. Komentarz. Toruń: Towarzystwo Naukowe Organizacji i Kierownictwa „Dom Organizatora”, 2002. 